UNDERGRADUATE RESEARCH IN NATURAL AND CLINICAL SCIENCE AND TECHNOLOGY (URNCST) JOURNAL Read more URNCST Journal articles and submit your own today at: https://www.urncst.com

\title{
Facilitating the Bloom of Intestinal Flora: Observing the Influence of Tetrahydrocannabinol (THC) on Beneficial Bacteria Inhabiting the Intestinal Microbiota
}

\author{
Simona Gindin, BHSc Student [1]*, Esha Karia, BHSc Student [1], \\ Alisiya Petrushkevich, BHSc Student [1], Shadi Sadeghian, BHSc Student [1] \\ [1] Faculty of Health Sciences, McMaster University \\ *Corresponding Author: gindins@ mcmaster.ca
}

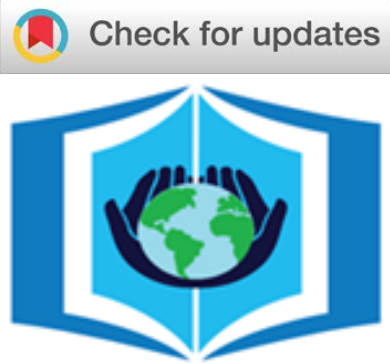

URNCST Journal

"Research in Earnest"

\begin{abstract}
Healthy human bodies are inhabited by over 100 trillion bacterial cells [1]. The study of the symbiotic relationship between humans and these unicellular organisms has become of great importance in the medical field. In fact, the pathology of many diseases involves perturbation of the intestinal flora [1]. Tetrahydrocannabinol (THC), the psychotropic ingredient of cannabis, has caught the attention of healthcare researchers given its ability to increase appetite, and reduce nausea and inflammation [2]. THC has also been associated with modulating the effects arising in the endocannabinoid system (ECS), however, its ability to affect bacteria growth has not been studied [3]. This proposed experiment seeks to explore the growth and vitality of beneficial gut microbiota (Lactobacillus acidophilus (LA), Akkermansia muciniphila (AM), Bifidobacterium bifidum (BB), and Streptococcus thermophilus (ST)) upon exposure to THC [4]. Through utilizing an experimental approach, beneficial bacterial cultures will be collected to study the growth of the microorganisms incubated with THC, relative to a positive and negative control. The results of the proposed study could inform future experiments investigating the treatment of a range of diseases with cannabis. The benefits of these treatments could also be extended to improving the daily health of the general population.
\end{abstract}

Keywords: culture collection; endocannabinoid system; gastrointestinal pathology; gut microbiota; human microbiome; intestinal health; in-vitro; tetrahydrocannabinol (THC); receptors

\section{Introduction}

Recent medical discoveries have highlighted the importance of the human microbiome, which has caused a rising concern for gut health in the general population [5]. The prevalent use of probiotics and prebiotics has driven an interest in exploring the effects of tetrahydrocannabinol (THC) on gut microbiota [4]. These microorganisms located in the small and large intestines are instrumental to digestive health, and play a role in modulating diseases of the gastrointestinal (GI) system [6]. The intestinal lining of the digestive tract contains endocannabinoid receptors $\left(\mathrm{CB}_{1}\right)$ and $\left(\mathrm{CB}_{2}\right)$, which make up a small part of the larger endocannabinoid system (ECS) found throughout the entire body [7]. The ECS is responsible for many functions, including fulfilling homeostatic roles and modulating inflammation, hunger, metabolism, and pain [3]. The acute administration of $\mathrm{THC}, \mathrm{a} \mathrm{CB}_{1}$ and $\mathrm{CB}_{2}$ receptor agonist, can result in the upregulation of the ECS in the GI tract [7].

A recent study by Mehrpouya-Bahrami et al. (2017) has demonstrated that a blockade of the $\mathrm{CB}_{1}$ receptor aids in the mitigation of diet-induced obesity (DIO), reduces inflammation, and increases the relative abundance of $A M$, a bacterium with beneficial effects on metabolism [7]. Blocking the $\mathrm{CB}_{1}$ receptor may alter the gut microbiota, and chronic administration of THC may influence the growth of beneficial bacteria [7]. Given the scarcity of research studying the relationship between THC and the microbiota, the nature of this association is currently unknown.

Given that the components of the ECS modulate the function of the GI tract, we propose a novel study that explores THC's effects on the growth of gut microbiota. This will help expand the known therapeutic effects of THC and broaden the scope of future medicinal treatment.

We propose that THC will influence the growth of the beneficial bacteria that inhabit the human digestive system. Studies have been conducted surrounding the implications of THC and bacterial responses. Aside from the aforementioned studies, a report done in 2016 investigated the impact of antagonists on receptors in the ECS [8]. A bacterium strain, $L A$, exposed to $\mathrm{THC}$, stimulated $\mathrm{CB}_{1}$ and $\mathrm{CB}_{2}$ receptors when digested by the body [9]. It can be noted that scientists have thoroughly studied the influence of THC on human intestinal cells. However, no reputable research has been conducted on the relationship between THC and the human microbiome specifically, thus far. Therefore, the execution of our study is imperative in developing this association. Beneficial gut bacteria, such as $L A, B B, A M$, and $S T$, will be tested with the presence of THC, and their growth will be 
UNDERGRADUATE RESEARCH IN NATURAL AND CLINICAL SCIENCE AND TECHNOLOGY (URNCST) JOURNAL Read more URNCST Journal articles and submit your own today at: https://www.urncst.com

calculated [4]. By exploring the role that THC plays in the growth of gut bacteria that are instrumental to the health of the microbiome, a new usage of THC can be determined.

\section{Methods}

We chose an in-vitro experimental approach in order to loosely mimic the physiological living conditions of bacteria inhabiting the small and large intestines in an effort to decipher how THC affects its growth. Specifically, the experiment involves the in-vitro analysis of bacterial growth through the use of cell cultures. The procedure will involve creating the ideal survival conditions for a slurry of "good" gut bacteria. This includes the bacteria $L A, A M, B B$, and $S T$, all of which are available for purchase from the American Type Culture Collection (ATCC) [4].

The pre-calculated concentration of the bacterial solution will be spread across three separate agar plates; each plate will be exposed to a different condition, depending on whether it is a positive control, negative control, or experimental plate. A $2.1 \%$ solution of THC will be added to the experimental petri dish. The positive control will be incubated along with a $10 \mathrm{~mL}$ solution with a $2.1 \%$ concentration of tetracycline, whilst the negative control will be incubated with an equal mass of water. This will account for the possibility of experimental error confounding the results. These concentrations were inspired by a related experiment conducted by the Journal of Natural Products, which measured the antibacterial properties of cannabis using Staphylococcus aureus and the same percent active ingredient [10]. To determine the growth, the number of colony-forming units (CFU) per millilitre of starting culture will be calculated following a 72 hour incubation period [10].

A secondary aspect of this experiment will involve adding increasing concentrations of THC to a liquid culture in increments of $1 \%$ per $10 \mathrm{~mL}$, starting at a $0.0 \%$ THC solution and ending at $100 \%$. This will yield a dose-response relationship between THC and bacterial growth, and will demonstrate the saturability of this relationship.

This methodology possesses inherent limitations, including a lack of control over simulating the exact temperature and $\mathrm{pH}$ of the intestinal tract, and the limited sample of bacteria used. Also, it does not account for variation in the way each bacterial strain responds to THC. Regardless, the experiment allows the group to establish a general relationship between cannabis and the robustness of the human microbiome

\section{Conclusion}

Current research suggests that consumption of marijuana will increase following its legalization in Canada [2]. Identifying the full scope of its effects on the body is imperative in broadening its medical applications. The results of the study could complement MehrpouyaBahrami and colleagues' 2017 study: implementing the administration of THC to offset diet-induced obesity, by increasing the growth of $A M$ in the intestines [7].

Data collected in this study could play a role in developing a better treatment of Recurrent Clostridium Difficile Infection (RCDI). Fecal enemas are used to restore normal intestinal flora by transplanting healthy gut microbiota. Fecal transplantation in RCDI could be replaced with treatments of marijuana. Patients would no longer need a suitable fecal donor and would avoid common transplantation side effects [11].

Further research could be conducted to observe the effects of THC on the gut microbiome in non-ideal conditions, such as a murine model. These results would more closely model the effects of THC on the human microbiome. Then, research should be conducted to derive similar effects on the microbiome from the use of cannabidiol, thus eliminating the mind-altering effects of THC during treatment. Our findings challenge the idea that marijuana can simply be used to improve the quality of life of patients affected by certain diseases and disorders; instead, marijuana may prove to be a valuable method of fostering the growth of healthy gut bacteria.

\section{List of Abbreviations}

LA: Lactobacillus acidophilus

AM: Akkermansia muciniphila

BB: Bifidobacterium bifidum

ST: Streptococcus thermophilus

THC: Tetrahydrocannabinol

GI: gastrointestinal

$\mathbf{C B}_{1}$ : Cannabinoid receptor 1

$\mathbf{C B}_{2}$ : Cannabinoid receptor 2

ECS: Endocannabinoid system

DIO: Diet-induced obesity

ATCC: American Type Culture Collection

CFU: Colony forming units

RCDI: Recurrent Clostridium Difficile Infection

\section{Definitions}

Agonist: Molecule that binds to a receptor and activates the receptor to produce a biological response.

Antagonism: Interference or inhibition of binding to a receptor on a cell.

Cannabinoid receptors: G-protein coupled receptors that cannabinoids (e.g THC, CBD) binds to. There are two types of cannabinoid receptors- $\mathrm{CB}_{1}$ and $\mathrm{CB}_{2}$ and THC binds to both of them.

Colony Forming Unit (CFU)/mL = (Number of colonies) (Dilution factor) / Volume of culture plate.

Endocannabinoid system: A biological system of the body composed of cannabinoid receptors. It plays an important role in Central Nervous System (CNS) development and responses to endogenous and exogenous cannabinoids. 
UNDERGRADUATE RESEARCH IN NATURAL AND CLINICAL SCIENCE AND TECHNOLOGY (URNCST) JOURNAL Read more URNCST Journal articles and submit your own today at: https://www.urncst.com

"Good" Bacteria: Bacteria that is beneficial to the gut (small and large intestines), defined in this paper as Lactobacillus acidophilus, Bifidobacterium bifidum, Akkermansia muciniphila, and Streptococcus thermophilus. Microbiome: A community of microorganisms that inhabit a specific environment or area of the body. Microbiota: Bacteria inhabiting the small and large intestines.

Probiotics: Food or dietary supplements such as yogurt, sauerkraut and kefir that supply beneficial bacteria to the intestines.

Prebiotics: A form of dietary fibre that acts as a fertilizer for "good" bacteria growth.

Recurrent Clostridium Difficile Infection (RCDI): A bacterial infection that causes nosocomial diarrhea. Tetracycline: A broad-spectrum of antibiotics, with a molecular structure of four rings, effective against a variety of organisms.

\section{Conflicts of Interest}

The authors declare no conflicts of interest.

Ethics Approval and/or Participant Consent

This proposal did not require ethics approval, as it was a protocol designed for a case competition.

\section{Authors' Contributions}

SG: made contributions to the research involving the study background and the writing of the introduction, contributed to the editing and reviewing processes, gave final approval of the version to be published.

EK: contributed to writing the introduction, as well as research into the background of the proposal, contributed to the editing and reviewing processes, gave final approval of the version to be published.

AP: wrote the conclusion section, and provided insight into future directions of this study, contributed to the editing and reviewing processes, gave final approval of the version to be published.

SS: completed the research and writing behind the methodology of the proposal, contributed to the editing and reviewing processes, gave final approval of the version to be published.

\section{Acknowledgements}

The authors would like to acknowledge Scinapse McMaster for their mentorship throughout the research process.

\section{Funding}

This study was not funded.

\section{References}

[1] Guinane C M, Cotter P D. Role of the gut microbiota in health and chronic gastrointestinal disease:
Understanding a hidden metabolic organ. National Center for Biotechnology Information. $2013 \mathrm{Mar}$ 26;6(4):295-308. https://doi.org/10.1177/1756283X13482996.

[2] Maxwell JC, Mendelson B. What Do We Know Now About the Impact of the Laws Related to Marijuana?. J Addict Med. 2016 Jan-Feb;10(1):3-12. https://doi.org/10.1097/ADM.0000000000000188.

[3] McPartland JM, Guy GW, Di Marzo V. Care and Feeding of the Endocannabinoid System: A Systematic Review of Potential Clinical Interventions that Upregulate the Endocannabinoid System. PLOS One. 2014 Mar 12;9(3):1-21. https://doi.org/10.1371/journal.pone.0089566.

[4] DiPardo R. SF Gate. [cited 2018 Nov 22] Available from: https://healthyeating.sfgate.com/listgood-bacteria-7771.html.

[5] Holmes E, Li J, Athanasiou T, Ashrafian H, Nicholson JK. Understanding the role of gut microbiome-host metabolic signal disruption in health and disease. Trends in Microbiology. 2011 Jul;19(7):349-359. https://doi.org/10.1016/j.tim.2011.05.006.

[6] Marchesi J, Adams D, Fava F, Hermes G, Hirschfield G, Hold G, et al. The gut microbiota and host health: A new clinical frontier. Gut. 2015 Feb;65(2):330-339. https://doi.org/10.1136/gutjnl-2015-309990.

[7] Mehrpouya-Bahrami P, Chitrala KN, Ganewatta M, Tang C, Murphy A, Enos RT, et al. Blockade of $\mathrm{CB}_{1}$ cannabinoid receptor alters gut microbiota and attenuates inflammation and diet-induced obesity. Scholars Portal Journals. 2017 Nov 15;7(1):15645. http://doi.org/10.1038/s41598-017-15154-6.

[8] Russo EB. Beyond Cannabis: Plants and the Endocannabinoid System. Trends in Pharmacological Sciences. 2016 Jul;37(7):594-605. http://doi.org/10.1016/j.tips.2016.04.005.

[9] DiPatrizio N. Endocannabinoids in the Gut. Cannabis Cannabinoids Research. 2016;1(1):67-77. http://doi.org/10.1089/can.2016.0001.

[10] Appendino G, Gibbons S, Giana A, Pagani A, Grassi G, Stavri M, et al. Antibacterial Cannabinoids from Cannabis sativa: A Structure-Activity Study. Journal of Natural Products. 2008 Aug 6;71(8):1427-1430. http://doi.org/10.1021/np8002673.

[11] Li X, Gao X, Hu H, Xiao Y, Li D, Yun G,et al. Clinical Efficacy and Microbiome Changes Following Fecal Microbiota Transplantation in Children With Recurrent Clostridium Difficile Infection. Frontiers in Microbiology. 2018 Nov 2;9:1-8. http://doi.org/10.3389/fmicb.2018.02622. 


\section{Article Information}

Managing Editor: Jeremy Y. Ng

Peer Reviewers: Bi-ru Amy Yeung, Jennifer Williams

Article Dates: Received Nov 11 19; Accepted Dec 21 19; Published Jan 0920

\section{Citation}

Simona G, Esha K, Alisiya P, Shadi S. Facilitating the bloom of intestinal flora: Observing the influence of tetrahydrocannabinol (THC) on beneficial bacteria inhabiting the intestinal microbiota. URNCST Journal. 2020 Jan 09: Vol 4(1).

https://urncst.com/index.php/urncst/article/view/171

DOI Link: https://doi.org/10.26685/urncst.171

\section{Copyright}

(C) Simona Gindin, Esha Karia, Alisiya Petrushkevich, Shadi Sadeghian (2020). Published first in the Undergraduate Research in Natural and Clinical Science and Technology (URNCST) Journal. This is an open access article distributed under the terms of the Creative Commons Attribution License (https://creativecommons.org/licenses/by/4.0/), which permits unrestricted use, distribution, and reproduction in any medium, provided the original work, first published in the Undergraduate Research in Natural and Clinical Science and Technology (URNCST) Journal, is properly cited. The complete bibliographic information, a link to the original publication on http://www.urncst.com, as well as this copyright and license information must be included.

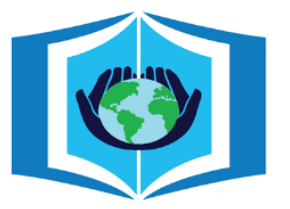

\section{URNCST Journal}

"Research in Earnest"

\section{Funded by the \\ Government \\ of Canada}

\section{Canadà̀}

Do you research in earnest? Submit your next undergraduate research article to the URNCST Journal!

| Open Access | Peer-Reviewed | Rapid Turnaround Time | International |

| Broad and Multidisciplinary | Indexed | Innovative | Social Media Promoted |

Pre-submission inquiries? Send us an email at info@ urncst.com | Facebook, Twitter and LinkedIn: @URNCST

Submit YOUR manuscript today at https://www.urncst.com! 